\title{
Deleterious consequences of a red tide dinoflagellate Cochlodinium polykrikoides for the calanoid copepod Acartia tonsa
}

\author{
Xiaodong Jiang*, Yingzhong Tang, Darcy J. Lonsdale, Christopher J. Gobler
}

School of Marine and Atmospheric Sciences, Stony Brook University, Stony Brook, New York 11794-5000, USA

\begin{abstract}
The dinoflagellate Cochlodinium polykrikoides Margalef has formed dense blooms and caused severe fish kills on a global scale in recent decades. Survivorship, feeding, and fecundity of the copepod Acartia tonsa Dana fed C. polykrikoides were investigated to assess potential impacts of these harmful events on herbivores. Survivorship of female A. tonsa was significantly reduced with increasing C. polykrikoides concentrations from 900 to $4700 \mu \mathrm{g} \mathrm{Cl}^{-1}$ (500 to $2600 \mathrm{cells} \mathrm{ml}^{-1}$ ). Copepods suffered $100 \%$ mortality within $1.5 \mathrm{~d}$ at C. polykrikoides concentrations of 3300 and $4700 \mu \mathrm{g} \mathrm{C}$

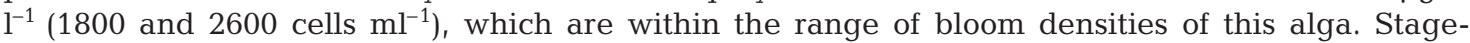
specific mortality of $A$. tonsa showed that copepod susceptibility to $C$. polykrikoides decreased with development. Two bioassay experiments suggested that copepod mortality was due to multiple harmful compounds produced by C. polykrikoides. Ingestion rates of A. tonsa fed C. polykrikoides were 25 to $60 \%$ lower than ingestion rates of non-toxic Rhodomonas lens Pascher and Ruttner when the food concentrations ranged from 150 to $1500 \mathrm{\mu g} \mathrm{Cl}^{-1}$. C. polykrikoides supported higher egg production rates of $A$. tonsa than $R$. lens at the low algal concentrations (18 to $180 \mu \mathrm{g} \mathrm{C}^{-1}$ ), while egg production rates of $A$. tonsa fed C. polykrikoides were significantly less than those fed $R$. lens when

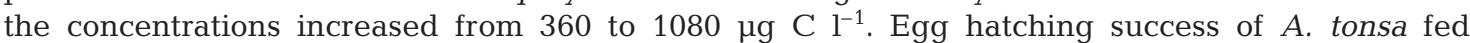
C. polykrikoides ranging from 90 to $1080 \mu \mathrm{g} \mathrm{Cl}^{-1}$ was very low (20 to $43 \%$ ) compared to the higher values when fed $R$. lens (83 to $100 \%$ ). Egg sizes of A. tonsa fed C. polykrikoides were significantly lower than those fed $R$. lens. All of these deleterious consequences may lead to $A$. tonsa population collapses during C. polykrikoides blooms.
\end{abstract}

KEY WORDS: Harmful algae $\cdot$ Copepods $\cdot$ Survivorship $\cdot$ Feeding $\cdot$ Fecundity $\cdot$ Cochlodinium polykrikoides · Acartia tonsa

\section{INTRODUCTION}

Harmful algal blooms (HABs) have increased in frequency, duration, and distribution in recent decades. Fish kills and accumulation of phycotoxins in shellfish with subsequent poisoning of humans have been well documented. However, studies of the interactions between harmful algae and their zooplankton grazers have been less common, and results are often controversial (Turner \& Tester 1997, Turner 2006). These complex and inconsistent interactions are partly due to the wide variety of phycotoxins associated with $>200$ algal species from 20 genera (Landsberg 2002), substantial changes in toxicity levels of a single algal clone with culture age and nutrients (Granéli \& Flynn 2006), and variations of grazers in terms of feeding patterns, binding sites of toxins, and structures of nervous systems (Turner \& Tester 1997). Furthermore, phenotypic plasticity and rapid evolution of resistance to harmful algae can significantly shape the interactions between algae and herbivores (Hairston et al. 1999, Colin \& Dam 2004).

Despite this complexity, zooplankton grazers are often considered to be adversely affected by harmful 
algae. Effects include impaired feeding, avoidance behavior, physiological dysfunction, depressed growth and reproduction, and reduced population fitness (Turner \& Tester 1997, Landsberg 2002, Prince et al. 2006, Barreiro et al. 2007, Cohen et al. 2007, Flynn \& Irigoien 2009). Reduced feeding rates of zooplankton may be due to behavioral rejection of harmful algae prior to ingestion or physiological incapacitation (Ives 1987). Inability to continue feeding may result in low growth and reproduction, eventually causing a decline in population abundance. Zooplankton grazing may impact the development and termination of HABs. However, many studies suggest that the top-down controls are limited due to poisoning of grazers by phycotoxins and/or their relatively low growth rate (reviewed by Turner \& Tester 1997). Beyond directly feeding on harmful algae, zooplankton grazing may transport toxins along the food web and they may serve as vectors for higher trophic levels (Jester et al. 2009).

The unarmored, chain-forming, gyrodinioid dinoflagellate Cochlodinium polykrikoides Margalef has formed dense blooms and caused severe economic damage in Southeast Asia during the past 2 decades (Lee 2008). Recently, C. polykrikoides blooms have been documented in many coastal waters ranging throughout temperate, subtropical, and tropical latitudes in both Asia and North America (Anton et al. 2008, Curtiss et al. 2008, Gobler et al. 2008, Park et al. 2009). Cell densities during blooms usually range from $10^{3}$ to $10^{4}$ cells ml $^{-1}$ (Anton et al. 2008, Curtiss et al. 2008, Gobler et al. 2008, Park et al. 2009). Bloom patches can achieve cell densities exceeding $10^{5}$ cells $\mathrm{ml}^{-1}$ (Gobler et al. 2008). C. polykrikoides isolated in East Asia can be mixotrophic, feeding on small phytoplankton species $(<11 \mu \mathrm{m})$ by engulfing the prey through the sulcus (Jeong et al. 2004). Strong diel vertical migration has been observed in field populations of C. polykrikoides (Park et al. 2001). C. polykrikoides appears to be resistant to attack by 6 algicidal bacteria (Imai \& Kimura 2008), and, in turn, C. polykrikoides inhibits growth of the dinoflagellate Akashiwo sanguinea and caused morphologically abnormal cells (Yamasaki et al. 2007). All of these attributes likely provide $C$. polykrikoides with competitive advantages over other occurring microalgae and, at least partly, explain the mechanisms of C. polykrikoides bloom formation.

Although the emergence of Cochlodinium polykrikoides blooms and subsequent severe fish kills have been well recorded, the precise toxic mechanisms of this alga are still poorly understood. C. polykrikoides blooms occurring along the coast of Japan were reported to release water-soluble ichthyotoxic substances with characteristics of paralytic shellfish toxins
(Onoue et al. 1985) and 3 toxin fractions: neurotoxic, hemolytic and hemagglutinative (Onoue \& Nozawa 1989). In Korean isolates, C. polykrikoides has been reported to generate the superoxide anion $\left(\mathrm{O}_{2}{ }^{-}\right)$and hydrogen peroxide $\left(\mathrm{H}_{2} \mathrm{O}_{2}\right)$ (Kim et al. 1999), which resulted in the inactivation of transport-related enzyme activities in fish gills, a drop in blood $\mathrm{pO}_{2}$, and abnormal secretion of gill mucus (Kim et al. 2000). Interestingly, the production of reactive oxygen species (ROS) in 2 C. polykrikoides strains isolated in Japanese waters was very low compared to Chattonella marina, a species well known for ROS production. Fish kills by these 2 strains were related to biologically active metabolites, such as cytotoxic agents and mucus substances (Kim et al. 2002). Further, the harmful effects of $C$. polykrikoides from the US east coast waters to fish was caused by a labile, extracellular toxic principle produced by actively growing cells (Tang \& Gobler 2009).

The interactions between Cochlodinium polykrikoides and zooplankton have been poorly studied. $C$. polykrikoides retarded metamorphosis of the Pacific oyster Crassostrea gigas from the trochophore stage to the D-shaped larval stage (Matsuyama et al. 2001). Egg production rates and egg viability of the copepod Acartia omorii were low when fed C. polykrikoides (Shin et al. 2003). In contrast, the planktonic ciliate Strombidinopsis sp. ingested C. polykrikoides and grew well (Jeong et al. 2008). In the present study, the deleterious effects of $C$. polykrikoides on survival, feeding, and fecundity of the copepod A. tonsa Dana were investigated to assess potential impacts of harmful blooms on lower trophic grazers.

\section{MATERIALS AND METHODS}

Collection and culture of organisms. The dinoflagellate Cochlodinium polykrikoides clone CP1 was isolated from Peconic Bay, Long Island, New York in 2006 (Gobler et al. 2008). The flagellate Rhodomonas lens Pascher and Ruttner (CCMP 739) was obtained from the Provasoli-Guillard National Center for Culture of Marine Phytoplankton. The cultures were maintained in a temperature-controlled incubator at $20^{\circ} \mathrm{C}$ with a $14 \mathrm{~h}$ light: $10 \mathrm{~h}$ dark cycle (approximately $50 \mu \mathrm{mol}$ photons $\mathrm{m}^{-2} \mathrm{~s}^{-1}$ ). The cultures were maintained in exponential growth phase by biweekly dilution with $\mathrm{f} / 2$ medium. The length and width of $>100$ cells were measured under a compound microscope. The carbon contents of the 2 microalgae (Table 1) were estimated from their cell volumes (Stoecker et al. 1994).

The copepod Acartia tonsa was collected from Stony Brook Harbor, Long Island Sound, New York with a 
Table 1. Characteristics of 2 algae used in the experiments. ESD: equivalent

\begin{tabular}{|c|c|c|c|c|}
\hline Alga & $\begin{array}{l}\text { Length } \\
(\mu \mathrm{m})\end{array}$ & $\begin{array}{l}\text { Width } \\
(\mu \mathrm{m})\end{array}$ & $\begin{array}{l}\text { ESD } \\
(\mu \mathrm{m})\end{array}$ & $\begin{array}{l}\text { C content } \\
\left.(\mathrm{pg} \mathrm{cell})^{-1}\right)\end{array}$ \\
\hline Cochlodinium polykrikoides & $34 \pm 4.7$ & $27 \pm 4.1$ & 28.2 & 1816 \\
\hline Rhodomonas lens & $11 \pm 1.2$ & $7.0 \pm 1.0$ & 7.97 & 39.5 \\
\hline
\end{tabular}
spherical diameter

culture, or culture filtrate $(0.2 \mu \mathrm{m})$ of $C$. polykrikoides, or $0.2 \mu \mathrm{m}$ FSW (control). The culture density was $2200 \mu \mathrm{g} \mathrm{C} \mathrm{^{-1 }}$ $\left(1200\right.$ cells $\left.\mathrm{ml}^{-1}\right)$. The procedures were the same as for the acute toxicity experiment. Another experiment was designed to investigate whether the toxic reaction of copepods was dependent on physical contact with $202 \mu \mathrm{m}$ mesh plankton net. The population was continuously cultured in 201 tanks at a density of 20 to 50 ind. $\mathrm{l}^{-1}$. The copepods were offered Rhodomonas lens at a carbon concentration of approximately $500 \mu \mathrm{g}$ $\mathrm{C}^{-1}$ and maintained at $20^{\circ} \mathrm{C}$ with a $12 \mathrm{~h}$ light: $12 \mathrm{~h}$ dark cycle (approximately $1 \mu \mathrm{mol}$ photons $\mathrm{m}^{-2} \mathrm{~s}^{-1}$ ). The low irradiance level minimized the potential effects of light on copepods and algal growth during experiments. Half of the copepod culture medium was refreshed twice a week with $0.2 \mu \mathrm{m}$ filtered seawater (FSW).

Survival experiments. A life table experiment was performed to compare survivorship of Acartia tonsa when fed Cochlodinium polykrikoides at 5 concentrations ranging from 900 to $4700 \mu \mathrm{g} \mathrm{C} \mathrm{l^{-1 }}$ (500 to 2600 cells ml $^{-1}$ ). Our experimental concentrations were within the range of $C$. polykrikoides densities observed in the field (Gobler et al. 2008). Copepod survivorship in FSW and 2 Rhodomonas lens solutions

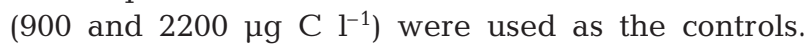
Approximately $400 \mathrm{~A}$. tonsa females were transferred into a $5 \mathrm{l}$ plastic container and acclimated in $0.2 \mu \mathrm{m}$ FSW for $24 \mathrm{~h}$. For each treatment, 20 to 48 healthy females were transferred individually into 6-well tissue culture plates. Each well was filled with $13 \mathrm{ml}$ of the food medium and $1 \mathrm{~A}$. tonsa. The copepods were checked every $12 \mathrm{~h}$ until they all died. Approximately $80 \%$ food medium was refreshed daily. All experiments were conducted in a temperature-controlled incubator at $20^{\circ} \mathrm{C}$ with a $12 \mathrm{~h}$ light: $12 \mathrm{~h}$ dark cycle (approximately $1 \mu \mathrm{mol}$ photons $\mathrm{m}^{-2} \mathrm{~s}^{-1}$ ).

An acute toxicity experiment was conducted to elucidate stage susceptibility of copepods to Cochlodinium polykrikoides. Acartia tonsa from the first and fourth naupliar stages (N1 and N4, respectively), the first and fourth copepodite stages ( $\mathrm{C} 1$ and $\mathrm{C} 4$, respectively), adult females, and eggs were exposed to a series of C. polykrikoides solutions ranging from 0 to $4700 \mu \mathrm{g} \mathrm{C}$ $\mathrm{l}^{-1}\left(0\right.$ to 2600 cells $\left.\mathrm{ml}^{-1}\right)$. Each treatment had 4 replicates. A. tonsa ( $\mathrm{n}=8$ to 12 ) were individually held in tissue culture plates filled with C. polykrikoides solutions. After $24 \mathrm{~h}$, the copepods were observed under a dissecting microscope.

The mode of harmful effects of Cochlodinium polykrikoides on copepods was explored using two $48 \mathrm{~h}$ bioassay experiments. Healthy Acartia tonsa females were exposed to either live culture, frozen and thawed
C. polykrikoides cells. The experiment was performed using cages made from polyethylene centrifuge tubes $(50 \mathrm{ml})$ with sealed nylon-mesh bottoms. The mesh sizes were 100 and $5 \mu \mathrm{m}$ for Treatments 1 and 2, respectively. Cages with $100 \mu \mathrm{m}$ mesh would permit the passage of C. polykrikoides cells while the $5 \mu \mathrm{m}$ mesh did not, which was verified by using the microscope. Each treatment had 4 replicates. Healthy females ( $n=8$ to 12 ) were transferred into each cage. The cages in Treatments 1 and 2 were immersed in a 41 culture of $C$. polykrikoides at a concentration of $2200 \mu \mathrm{g} \mathrm{C} \mathrm{l}^{-1}\left(1200\right.$ cells ml $\left.^{-1}\right)$. Cages with $5 \mu \mathrm{m}$ mesh were also immersed in 41 of $0.2 \mu \mathrm{m}$ FSW (control). Copepod mortality was compared after $48 \mathrm{~h}$.

Feeding experiments. Active adult copepods with intact appendages were transferred into 21 beakers with $0.2 \mu \mathrm{m}$ FSW for $24 \mathrm{~h}$ prior to the feeding experiments. Six food concentrations of Cochlodinium polykrikoides and Rhodomonas lens ranging from 150 to $1500 \mu \mathrm{g} \mathrm{C}^{-1}$ were used to determine copepod ingestion rates. We used 3 or 4 replicates of $250 \mathrm{ml}$ bottles for each experimental diet and concentration. The bottles without copepods were used as the controls. Ten active adult females were transferred into each bottle. The bottles were placed on a plankton wheel and rotated at $1 \mathrm{rpm}$ for $24 \mathrm{~h}$ at $20^{\circ} \mathrm{C}$ with a $12 \mathrm{~h}$ light: $12 \mathrm{~h}$ dark cycle (approximately $1 \mu \mathrm{mol}$ photons $\mathrm{m}^{-2} \mathrm{~s}^{-1}$ ). At the beginning and end of the experiment, samples for cell densities were taken. Algal densities were approximated by measuring in vivo chlorophyll fluorescence with a Turner AU-10 fluorometer. Actual cell densities were quantified on Lugol's iodine-preserved samples. In vivo fluorescence of C. polykrikoides and $R$. lens was significantly linearly related to algal concentration (regression coefficients: $\mathrm{r}=0.997$ and 0.999 , respectively; $\mathrm{p}<0.001$ for both; authors' unpubl. data). The significant relationships between fluorescence and algal concentration provided a rapid and simple measurement to monitor algal concentration during this experiment. The ingestion rates $(I)$ were calculated according to the equation described by Båmstedt et al. (2000):

$$
I=\frac{V \times \ln \frac{C_{t}^{\prime}}{C_{t}}}{t \times n} \times \frac{C_{0}+C_{t}}{2}
$$


where $C_{0}$ and $C_{t}$ are the food concentrations at the beginning and end of the experiment; $\mathrm{C}_{t}{ }^{\prime}$ is the final food concentration in the controls; $V$ is the volume of the bottles; $t$ is the duration of the experiment; and $n$ is the number of copepods.

Egg production and egg hatching experiments. Egg production rates and hatching success were measured at algal concentrations of 18,90, 180, 360, 540, and $1080 \mu \mathrm{g} \mathrm{C} \mathrm{l}^{-1}$. Approximately 300 healthy adult Acartia tonsa were transferred to each of 6 containers filled with $5 \mathrm{l}$ of the appropriate diet suspension and acclimated for $24 \mathrm{~h}$. Approximately $80 \%$ diet medium was refreshed daily. Two healthy female A. tonsa were then transferred from the container into a dish filled with $50 \mathrm{ml}$ food solution. A $200 \mu \mathrm{m}$ mesh was fixed above the bottom to minimize egg cannibalism. All eggs and nauplii were enumerated after a $24 \mathrm{~h}$ incubation. There were 7 replicates for each treatment. Eggs were placed individually in $1 \mathrm{ml}$ wells of a multidepression dish contained within a closed plastic box. Distilled water was added to the bottom of the box to reduce evaporation from the wells. Fresh FSW was added to the wells. Eggs were observed once a day for 2 to $3 \mathrm{~d}$. The measurements in the Cochlodinium polykrikoides treatments ran for $10 \mathrm{~d}$ or until all copepods in the containers were dead. The measurements in Rhodomonas lens treatments only ran for $1 \mathrm{~d}$.

Copepod egg sizes were measured when exposed to Cochlodinium polykrikoides and Rhodomonas lens at concentrations of $90,180,360,540$, and $720 \mu \mathrm{g} \mathrm{C} \mathrm{l}^{-1}$ during the $10 \mathrm{~d}$ period. Approximately 600 healthy Acartia tonsa adults were transferred to each of 5 containers filled with $10 \mathrm{l}$ of the appropriate diet suspension. Copepod eggs were collected by $60 \mu \mathrm{m}$ mesh and $80 \%$ food solutions were refreshed every day. At least 15 eggs from a sample were measured under a compound microscope using $100 \times$ magnification to determine the mean egg diameter.

Statistical analyses. Survivorship curves were compared using the GehanWilcoxon test (Pyke \& Thompson 1986). Lethal median concentration $\left(\mathrm{LC}_{50}\right)$ was determined by applying a probit analysis. One-way ANOVAs followed by Tukey multiple comparison tests were used to compare means of different treatments in bioassay experiments. A 2-level nested ANOVA was used to test the effects of algal species and concentration on ingestion rates. A 2-way ANOVA was used to analyze the effects of algal species and concentration on egg production rates and hatching success. A 3-way ANOVA was used to analyze the effects of algal species, concentration, and exposure time on egg sizes (Sokal \& Rohlf 1995). All statistical analyses were conducted using the SPSS 16.0 statistical package.

\section{RESULTS}

\section{Survival experiments}

Life table experiments revealed that survivorship of female Acartia tonsa was significantly reduced when fed Cochlodinium polykrikoides compared to those starved or fed non-toxic Rhodomonas lens (Fig. 1, Table 2). Survivorship of female A. tonsa significantly decreased with increasing $C$. polykrikoides concentrations (Fig. 1, Table 2). Female A. tonsa experienced rapid mortality at high (3300 and $4700 \mu \mathrm{g} \mathrm{C}$ $\mathrm{l}^{-1}$, or $\sim 1800$ and 2600 cells $\mathrm{ml}^{-1}$ ) and intermediate

Table 2. Acartia tonsa. Gehan-Wilcoxon test results of survivorship curves in the life table experiment. Arrow indicates whether the survivorship curve indicated by the column header is greater $(\uparrow)$ or less $(\downarrow)$ than that indicated in the row header. ${ }^{*} \mathrm{p}<0.05 ;{ }^{* *} \mathrm{p}<0.01 i^{* * *} \mathrm{p}<0.001$; ns: not significant; CP: Cochlodinium polykrikoides; RL: Rhodomonas lens; FSW: $0.2 \mu \mathrm{m}$ filtered seawater. Numbers indicate algal carbon concentrations $\left(\mu \mathrm{g} \mathrm{Cl}^{-1}\right)$

\begin{tabular}{|c|c|c|c|c|c|c|c|}
\hline & $\begin{array}{c}\text { CP } \\
900\end{array}$ & $\begin{array}{c}\text { CP } \\
1500\end{array}$ & $\begin{array}{c}\text { CP } \\
2200\end{array}$ & $\begin{array}{c}\text { CP } \\
3300\end{array}$ & $\begin{array}{c}\text { CP } \\
4700\end{array}$ & FSW & $\begin{array}{l}\text { RL } \\
900\end{array}$ \\
\hline CP 1500 & ${ }^{* * *} \uparrow$ & - & & & & & \\
\hline CP 2200 & $* * * \uparrow$ & ${ }^{* *} \uparrow$ & - & & & & \\
\hline CP 3300 & $* * * \uparrow$ & $* * * \uparrow$ & $* * * \uparrow$ & - & & & \\
\hline CP 4700 & ${ }^{* * *} \uparrow$ & $* * * \uparrow$ & $* * * \uparrow$ & ns & - & & \\
\hline FSW & ${ }^{*} \downarrow$ & $* * * \downarrow$ & $* * * \downarrow$ & $* * * \downarrow$ & $* * * \downarrow$ & - & \\
\hline RL 900 & ${ }^{*} \downarrow$ & $* * * \downarrow$ & $* * * \downarrow$ & $* * * \downarrow$ & $* * * \downarrow$ & ns & - \\
\hline RL 2200 & $* * * \downarrow$ & $* * * \downarrow$ & $* * * \downarrow$ & $* * * \downarrow$ & ${ }^{* * *} \downarrow$ & ${ }^{* *} \downarrow$ & ns \\
\hline
\end{tabular}

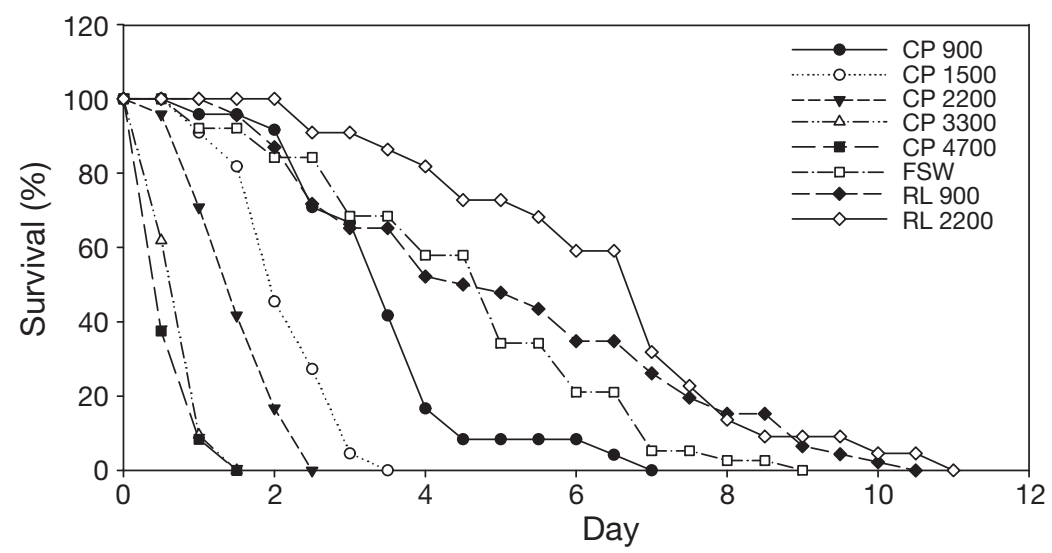

Fig. 1. Acartia tonsa. Survivorship when exposed to 5 Cochlodinium polykrikoides (CP) suspensions (900, 1500, 2200, 3300, and $\left.4700 \mu \mathrm{g} \mathrm{Cl}^{-1}\right), 2$ Rhodomonas lens (RL) suspensions (900 and $2200 \mu \mathrm{g} \mathrm{C} \mathrm{l}^{-1}$ ), and $0.2 \mu \mathrm{m}$ filtered seawater (FSW) 

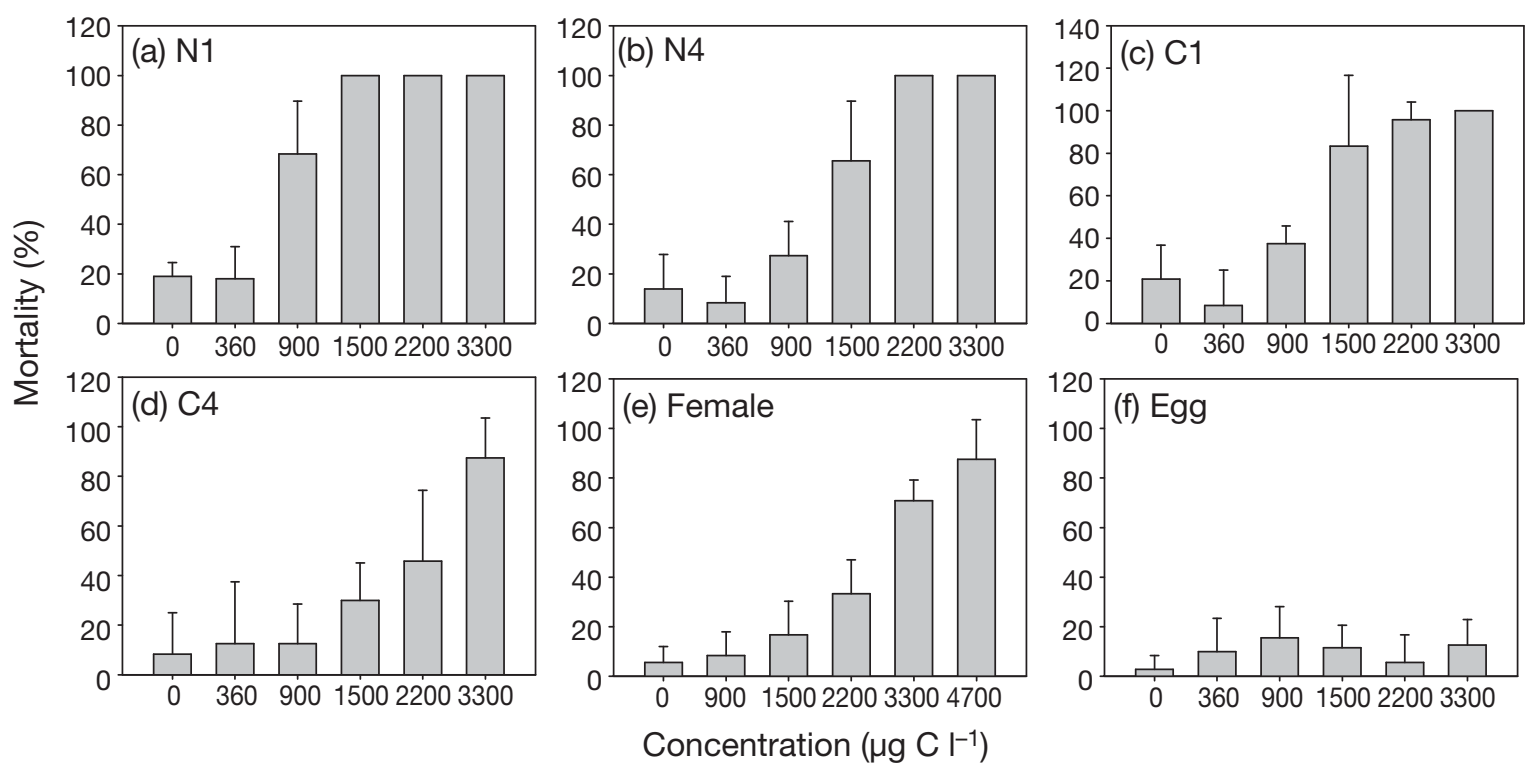

Fig. 2. Acartia tonsa. Stage-specific mortality (mean $\pm \mathrm{SD}$ ) when exposed to Cochlodinium polykrikoides for $24 \mathrm{~h}$. (a) N1, the first naupliar stage; (b) N4, the fourth naupliar stage; (c) C1, the first copepodite stage; (d) C4, the fourth copepodite stage; (e) adult female; (f) egg

(1500 and $2200 \mu \mathrm{g} \mathrm{C} \mathrm{l}^{-1}$, or $~ 800$ and 1200 cells ml $^{-1}$ ) concentrations of C. polykrikoides, with $100 \%$ of individuals expiring within 1.5 and $3.5 \mathrm{~d}$, respectively (Fig. 1). Survivorship of female A. tonsa fed $C$. polykrikoides was moderately improved at the low concentration of $900 \mathrm{\mu g} \mathrm{C} \mathrm{l}^{-1}\left(\sim 500 \mathrm{cells} \mathrm{ml}^{-1}\right)$, with individuals surviving $7 \mathrm{~d}$ (Fig. 1). All of these survival times were significantly shorter than those in

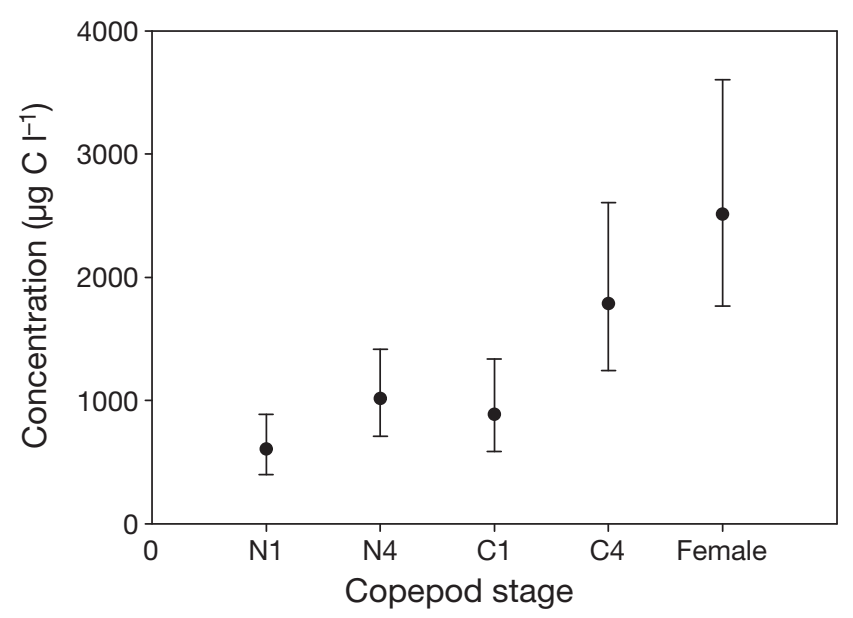

Fig. 3. Acartia tonsa. The $24 \mathrm{~h}$ lethal median concentration $\left(\mathrm{LC}_{50}\right)$ and $95 \%$ CIs for 5 development stages when exposed to Cochlodinium polykrikoides. N1 and N4: first and fourth naupliar stages; C1 and C4: first and fourth copepodite stages, respectively
FSW and in the $R$. lens control treatments (Fig. 1, Table 2).

Mortality of Acartia tonsa from early nauplii to adult females significantly increased with increasing Cochlodinium polykrikoides concentrations after a $24 \mathrm{~h}$ exposure ( $p<0.001$ for all, 1-way ANOVA; Fig. 2). In contrast, egg hatching was not affected by $C$. polykrikoides ( $p>0.05$, 1-way ANOVA; Fig. 2). LC 50 values indicated that the susceptibility of $A$. tonsa to C. polykrikoides decreased with development, especially from early copepodite to adult stage (Fig. 3). Early nauplii of $A$. tonsa were approximately 4 times more sensitive to C. polykrikoides than adult females after a $24 \mathrm{~h}$ exposure, with $\mathrm{LC}_{50} \mathrm{~S}$ of $607 \mu \mathrm{g} \mathrm{C}{ }^{-1}$ (334 cells ml ${ }^{-1}$; $95 \%$ CI: 399 to $877 \mu \mathrm{g} \mathrm{Cl}^{-1}$ or 220 to 483 cells ml$^{-1}$ ) and $2511 \mu \mathrm{g} \mathrm{Cl}^{-1}$ (1383 cells ml ${ }^{-1}$; $95 \%$ CI: 1769 to $3602 \mu \mathrm{g}$ $\mathrm{C}^{-1}$ or 974 to 1983 cells ml $^{-1}$ ), respectively.

Mortality of Acartia tonsa exposed to the frozen and thawed Cochlodinium polykrikoides culture was significantly reduced to half of that observed when copepods were exposed to the live culture (Fig. 4), but was significantly higher than that in FSW (Table 3). Copepods in the $0.2 \mu \mathrm{m}$ culture filtrate had significantly increased survivorship compared to those in the live culture, and their mortality did not significantly differ from that in FSW (Fig. 4, Table 3). Copepod mortality in the cages with $5 \mu \mathrm{m}$ nylon mesh and immersed in C. polykrikoides live culture was significantly lower than that in the cages with $100 \mu \mathrm{m}$ nylon mesh; however, it was significantly higher than that in FSW (Fig. 4, Table 3). 


\section{Feeding experiments}

The ingestion rates of Acartia tonsa were significantly affected by algal species $\left(F_{1,29}=10.2347, \mathrm{p}<\right.$ 0.01, 2-level nested ANOVA) and algal concentration $\left(F_{10,29}=2.9841, \mathrm{p}<0.05,2\right.$-level nested ANOVA $)$. The ingestion rates of $A$. tonsa fed Cochlodinium polykrikoides were 25 to $60 \%$ lower than ingestion rates of Rhodomonas lens (Fig. 5). The ingestion rates of $C$. polykrikoides and $R$. lens by $A$. tonsa significantly increased with increasing algal concentration $\left(F_{10,29}=\right.$

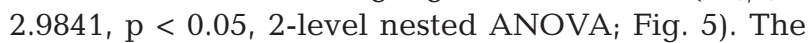
maximum daily ingestion rates were 3.15 and $6.18 \mu \mathrm{g} C$ ind. ${ }^{-1} \mathrm{~d}^{-1}$, respectively (Fig. 5).

\section{Egg production and egg hatching experiments}

The 2-way ANOVA showed that egg production rates of Acartia tonsa after a $1 \mathrm{~d}$ exposure were signif-

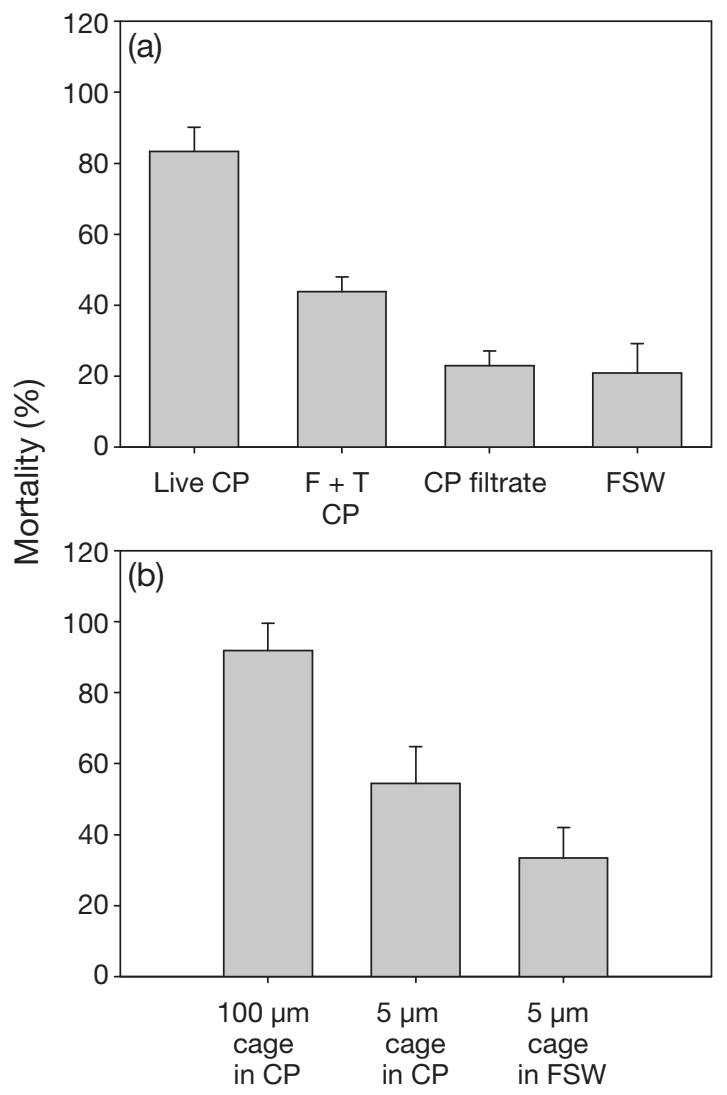

Fig. 4. Acartia tonsa. Bioassay experiments conducted for $48 \mathrm{~h}$. Percent mortality (mean $\pm \mathrm{SD}$ ) when (a) exposed to live Cochlodinium polykrikoides $(\mathrm{CP})$ culture, frozen and thawed $(\mathrm{F}+\mathrm{T})$ $\mathrm{CP}$ culture, $\mathrm{CP}$ culture filtrate $(0.2 \mu \mathrm{m})$, or $0.2 \mu \mathrm{m}$ filtered seawater (FSW); or (b) placed in cages covered with 5 or $100 \mu \mathrm{m}$ nylon mesh and immersed in live CP culture or $0.2 \mu \mathrm{m}$ FSW

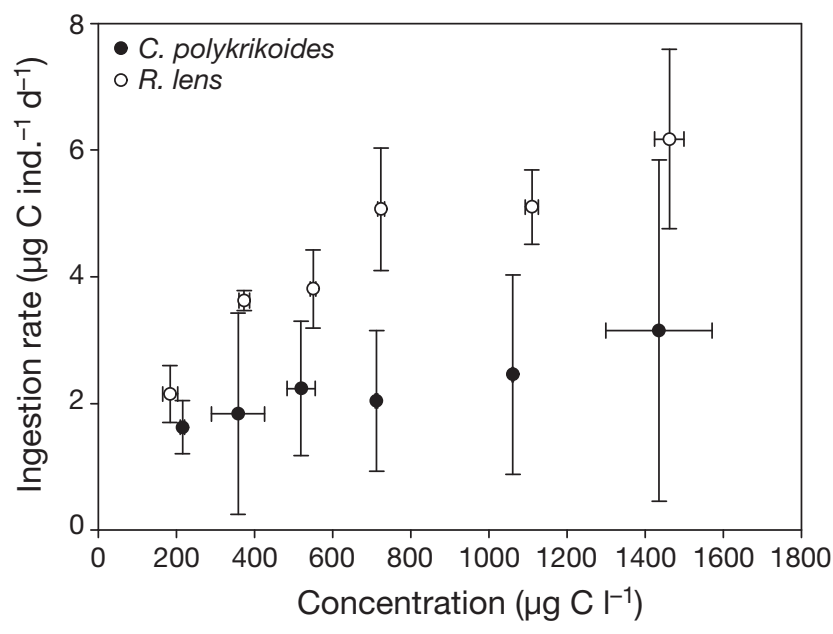

Fig. 5. Acartia tonsa. Ingestion rates (mean $\pm \mathrm{SD}$ ) when fed either Cochlodinium polykrikoides or Rhodomonas lens

icantly affected by algal species $\left(F_{1,60}=13.9295, \mathrm{p}<\right.$ 0.001), algal concentration $\left(F_{5,60}=8.0195, \mathrm{p}<0.001\right)$, and their interactions $\left(F_{5,60}=13.8806, \mathrm{p}<0.001\right)$. Egg production rates of $A$. tonsa increased progressively with increasing Rhodomonas lens concentration (Fig. 6). In contrast, egg production rates of A. tonsa moderately increased with increasing Cochlodinium

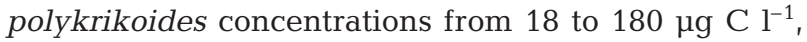
then were greatly reduced by the high concentrations of C. polykrikoides (360 to $1080 \mu \mathrm{g} \mathrm{C} \mathrm{l}^{-1}$; Fig. 6). C. polykrikoides supported higher egg production rates of $A$. tonsa than $R$. lens at low algal concentrations (18 to $180 \mu \mathrm{g} \mathrm{C} \mathrm{l}^{-1}$ ), while egg production rates of A. tonsa fed C. polykrikoides were greatly lower than those fed $R$. lens at high concentrations (360 to $1080 \mu \mathrm{g}$ $\mathrm{C}^{-1}$; Fig. 6). The 2-way ANOVA showed that egg hatching success of $A$. tonsa was significantly affected by algal species $\left(F_{1,48}=30.8405, \mathrm{p}<0.001\right)$, but not by algal concentration $\left(F_{51,48}=2.2991, \mathrm{p}=0.06\right)$. Egg hatching rates of $A$. tonsa were very high (82 to $100 \%$ ) when fed $R$. lens, except the values at the lowest con-

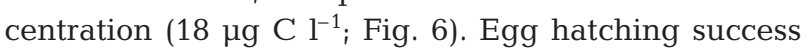
was very low, ranging from 20 to $43 \%$ when fed C. polykrikoides (Fig. 6).

The 2-way ANOVA showed that exposure time did not significantly change egg production rates $\left(F_{26,155}=\right.$ $1.5491, \mathrm{p}=0.055$; Fig. 7$)$ and hatching rates $\left(F_{26,142}=\right.$ 1.3164, p = 0.165; Fig. 8) of Acartia tonsa when fed Cochlodinium polykrikoides. The moderate concentrations of C. polykrikoides (90 to $360 \mu \mathrm{g} \mathrm{C}^{-1}$ ) supported higher egg production rates of $A$. tonsa than the lowest

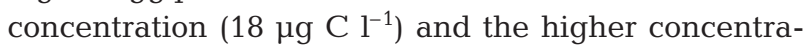
tions (540 and $1080 \mu \mathrm{g} \mathrm{Cl}^{-1}$, Fig. 7). Egg production of A. tonsa when fed C. polykrikoides at $90 \mu \mathrm{g} \mathrm{Cl}^{-1}$ persisted during the entire experiment $(10 \mathrm{~d})$. In contrast, egg production of $A$. tonsa only persisted for several 
Table 3. Acartia tonsa. Results of Tukey multiple comparison tests for mortality in 2 bioassay experiments. Healthy females were (a) exposed to live Cochlodinium polykrikoides $(\mathrm{CP})$ culture, frozen and thawed $(\mathrm{F}+\mathrm{T}) \mathrm{CP}$ culture, $\mathrm{CP}$ culture filtrate $(0.2 \mu \mathrm{m})$, or $0.2 \mu \mathrm{m}$ filtered seawater $(\mathrm{FSW})$; or $(\mathrm{b})$ placed in cages covered with 5 or $100 \mu \mathrm{m}$ nylon mesh and immersed in live CP culture or $0.2 \mu \mathrm{m}$ FSW. ${ }^{*} \mathrm{p}<0.05 ;{ }^{* *} \mathrm{p}<0.01 ;{ }^{* * *} \mathrm{p}<0.001 ;$ ns: not significant

\begin{tabular}{|c|c|c|c|c|c|c|}
\hline & $\begin{array}{l}\text { Live } \\
\text { LP } \\
\text { CP }\end{array}$ & $\begin{array}{c}\mathrm{F}+\mathrm{T} \\
\mathrm{CP}\end{array}$ & $\begin{array}{c}\mathrm{CP} \\
\text { filtrate }\end{array}$ & & $\begin{array}{l}-(\mathrm{b}) \\
100 \mu \mathrm{m} \\
\text { cage in CP }\end{array}$ & $\begin{array}{c}5 \mu \mathrm{m} \\
\text { cage in CP }\end{array}$ \\
\hline $\mathrm{F}+\mathrm{T} \mathrm{CP}$ & **** & - & & $5 \mu \mathrm{m}$ cage in $\mathrm{CP}$ & $* * *$ & - \\
\hline CP filtrate & $* * *$ & $* * *$ & - & $5 \mu \mathrm{m}$ cage in FSW & $* * *$ & $*$ \\
\hline FSW & *** & $* * *$ & $\mathrm{~ns}$ & & & \\
\hline
\end{tabular}

$\mathrm{C}^{-1}$ reduced $A$. tonsa egg hatching success to zero within $1 \mathrm{~d}$ (Fig. 8).

The 3-way ANOVA showed that Acartia tonsa egg sizes were significantly affected by algal species $\left(F_{1,2370}=89.337, \mathrm{p}<0.001\right)$, algal concentration $\left(F_{4,2370}=7.273, \mathrm{p}<0.001\right)$, and exposure time $\left(F_{9,2370}=2.35, \mathrm{p}<\right.$ 0.001; Fig. 9). Egg sizes of A. tonsa when fed Cochlodinium polykrikoides were lower than those fed Rhodomonas lens at each experimental concentration. The average egg sizes of A. tonsa when fed C. polykrikoides and $R$. lens for all concentrations were 76.40 and $77.60 \mu \mathrm{m}$, respectively. Egg sizes of $A$. tonsa when fed C. polykrikoides decreased from 77.30 to $75.96 \mu \mathrm{m}$ with increasing concentrations from 90 to $720 \mu \mathrm{g} \mathrm{Cl}^{-1}$. In contrast, egg sizes of $A$. tonsa remained constant (77.34 to $77.89 \mu \mathrm{m}$ ) when fed non-toxic $R$. lens from 90 to $720 \mu \mathrm{g} \mathrm{C}^{-1}$. The trend of egg sizes over time when fed either $C$. polykrikoides or $R$. lens was not clear (Fig. 9).

\section{DISCUSSION}

The present study showed that the dinoflagellate Cochlodinium polykrikoides had comparable or more deleterious impacts on copepods compared to other well-known toxic dinoflagellates. Acartia tonsa incurred $100 \%$ mortality within 1.5 and $3.5 \mathrm{~d}$, respectively, at high (3300 and $4700 \mu \mathrm{g} \mathrm{C}^{-1}, \sim 1800$ and 2600

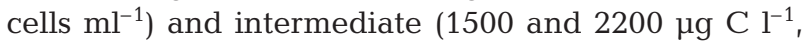
800 and 1200 cells $\mathrm{ml}^{-1}$ ) concentrations of C. polykrikoides. Approximately $50 \%$ of Acartia clausi died during a $7 \mathrm{~d}$ exposure to the toxic strain Alexandrium minutum at a density of 650 cells ml ${ }^{-1}$ (Barreiro et al. 2007). The dinoflagellate Karenia brevis cultured at densities ranging from $1.8 \times 10^{4}$ to $2.1 \times 10^{4} \mathrm{cells} \mathrm{ml}^{-1}$ led to approximately $80 \%$ mortality of Acartia tonsa over a period of $5 \mathrm{~d}$ (Prince et al. 2006). Cohen et al. (2007) reported that the Karenia brevis culture at a density of $1 \times 10^{4}$ cells ml ${ }^{-1}$ caused approximately $10 \%$ mortality in Temora turbinata, $3 \%$ mortality in Acartia tonsa, and $1 \%$ mortality in Centropages typicus after a $24 \mathrm{~h}$ exposure. Karlodinium corsicum (as Gyrodinium corsicum) at concentrations around $1500 \mu \mathrm{g} \mathrm{Cl}^{-1} \mathrm{killed}$ approximately $50 \%$ of Acartia grani after $6 \mathrm{~d}$ and all copepods after 12 d (da Costa et al. 2005). During blooms lasting 1 to 2 mo in US east coast waters, typi-

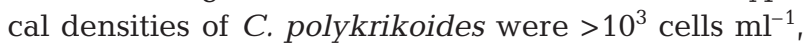
and frequently $10^{4}$ cells ml ${ }^{-1}$ (Gobler et al. 2008, Mulholland et al. 2009). Since lethal concentrations of $C$. polykrikoides for $A$. tonsa are lower than their densi- days at the lowest and 2 highest concentrations of C. polykrikoides. C. polykrikoides at $1080 \mu \mathrm{g} \mathrm{C} \mathrm{l^{-1 }}$ reduced $A$. tonsa egg production to zero within $2 \mathrm{~d}$ (Fig. 7). The hatching success of $A$. tonsa eggs when fed $C$. polykrikoides at 18 and $90 \mu \mathrm{C} \mathrm{C}^{-1}$ was higher than other concentrations. C. polykrikoides at $1080 \mu \mathrm{g}$ 

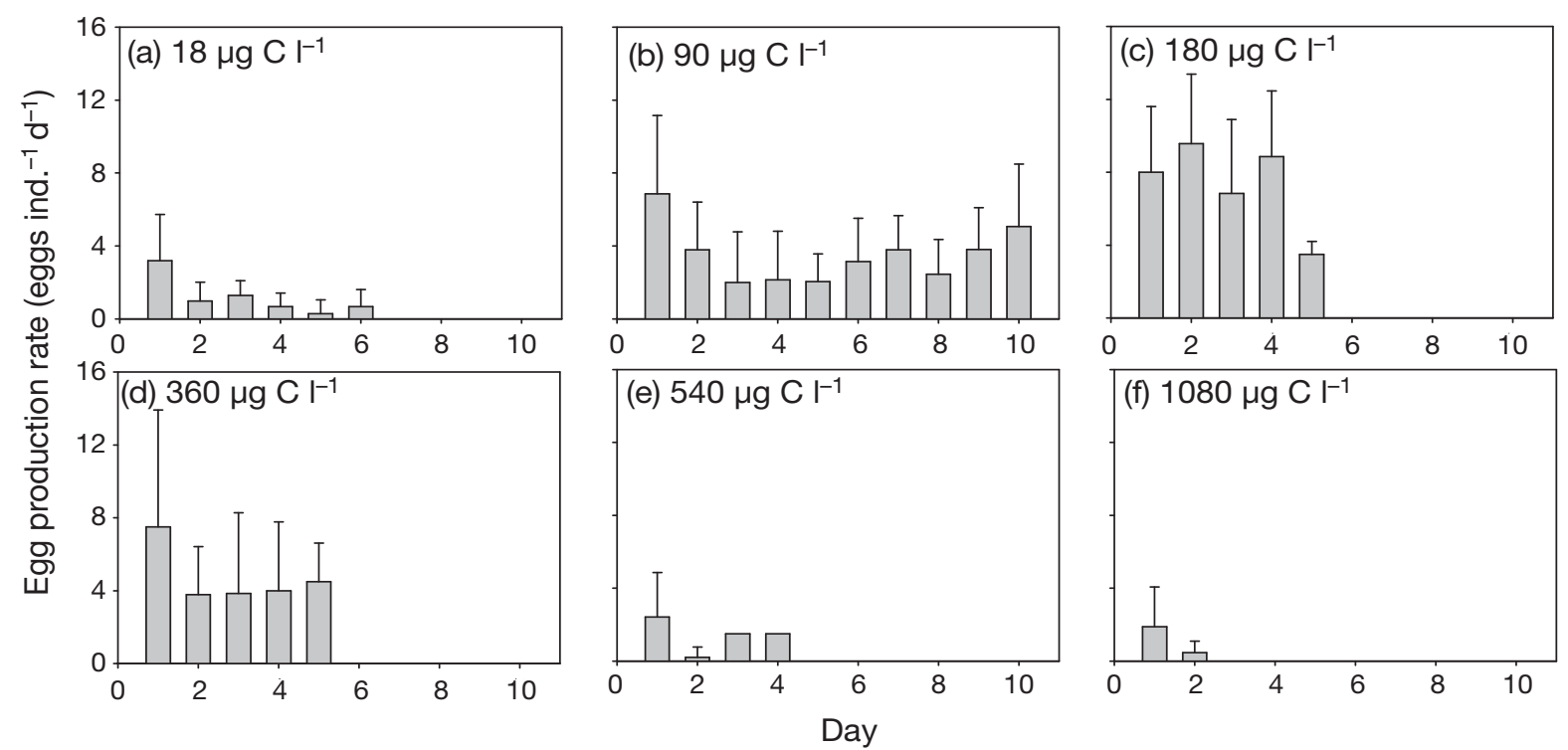

Fig. 7. Acartia tonsa. Egg production rates (mean $\pm \mathrm{SD}$ ) as a function of exposure time when fed Cochlodinium polykrikoides at concentrations of (a) 18, (b) 90, (c) 180, (d) 360, (e) 540, and (f) $1080 \mu \mathrm{g} \mathrm{C} \mathrm{l^{-1 }}$
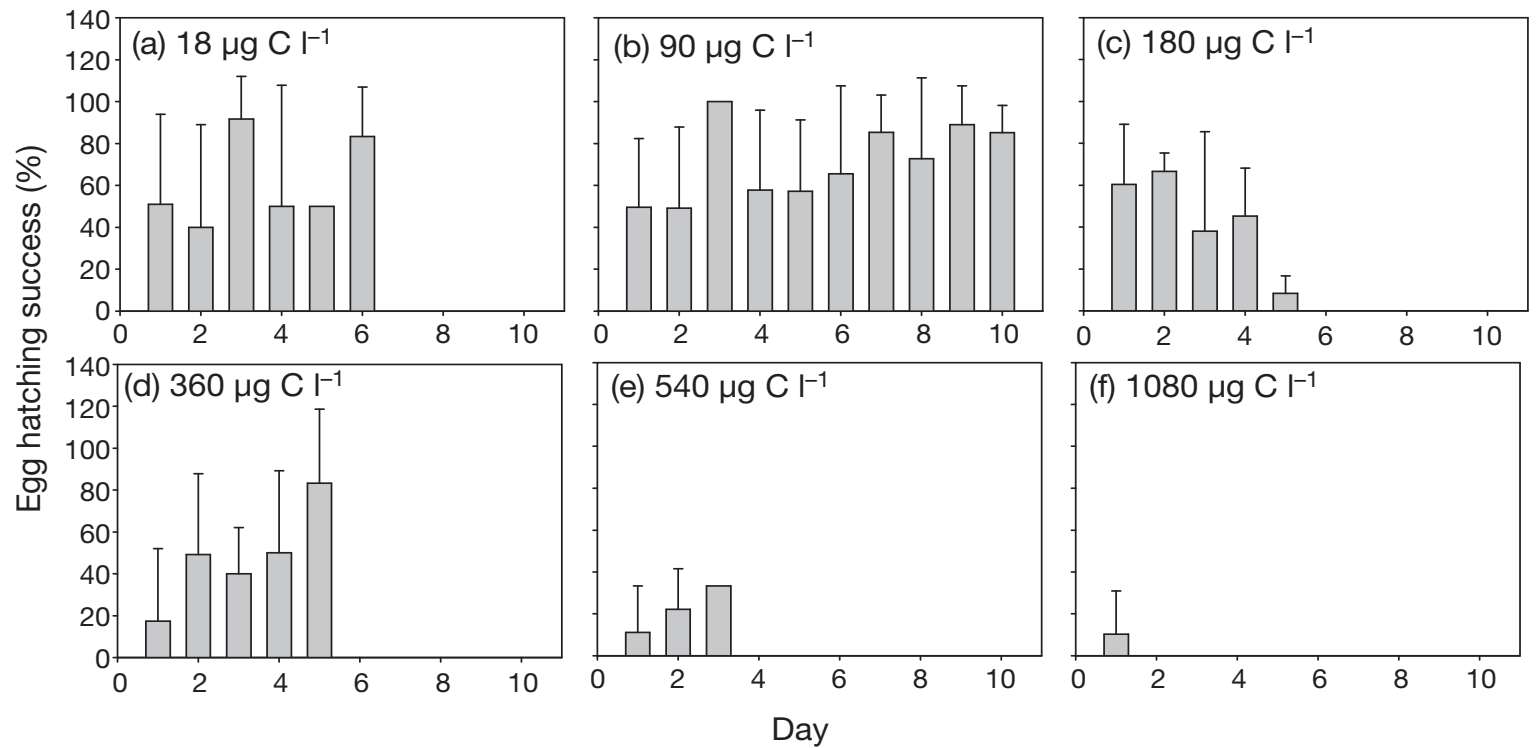

Fig. 8. Acartia tonsa. Egg hatching success (mean $\pm \mathrm{SD}$ ) as a function of exposure time when fed Cochlodinium polykrikoides at concentrations of (a) 18, (b) 90, (c) 180, (d) 360, (e) 540, and (f) $1080 \mu \mathrm{g} \mathrm{Cl}^{-1}$

ties during the blooms, exposure to high densities of toxic C. polykrikoides cells for such extended periods may cause substantial mortality within $A$. tonsa populations. The population dynamics of copepods are sensitive to variation in mortality, as a relatively small increase in female mortality can considerably change population growth by reducing recruitment. Even before blooms occur, the moderate densities of $C$. polykrikoides $\left(\sim 10^{2}\right.$ cells $\left.\mathrm{ml}^{-1}\right)$ may lead to adverse effects on zooplankton, such as reduced feeding and fecundity. Thus, toxic blooms may reduce secondary production and further lead to food restriction for consumers at higher trophic levels.

Extrapolating laboratory experiments to the natural environment can be complex. Rapid evolution of resistance may shape the interactions between zooplankton and toxic algae. Grazer populations that have experienced recurrent HABs can evolve local adaptations to toxic algae (Hairston et al. 1999, Colin \& Dam 2004). An artificial selection experiment showed that copepods evolved resistance to toxic algae over only 2 to 5 generations (Colin \& Dam 2004). The rapid evolution of 

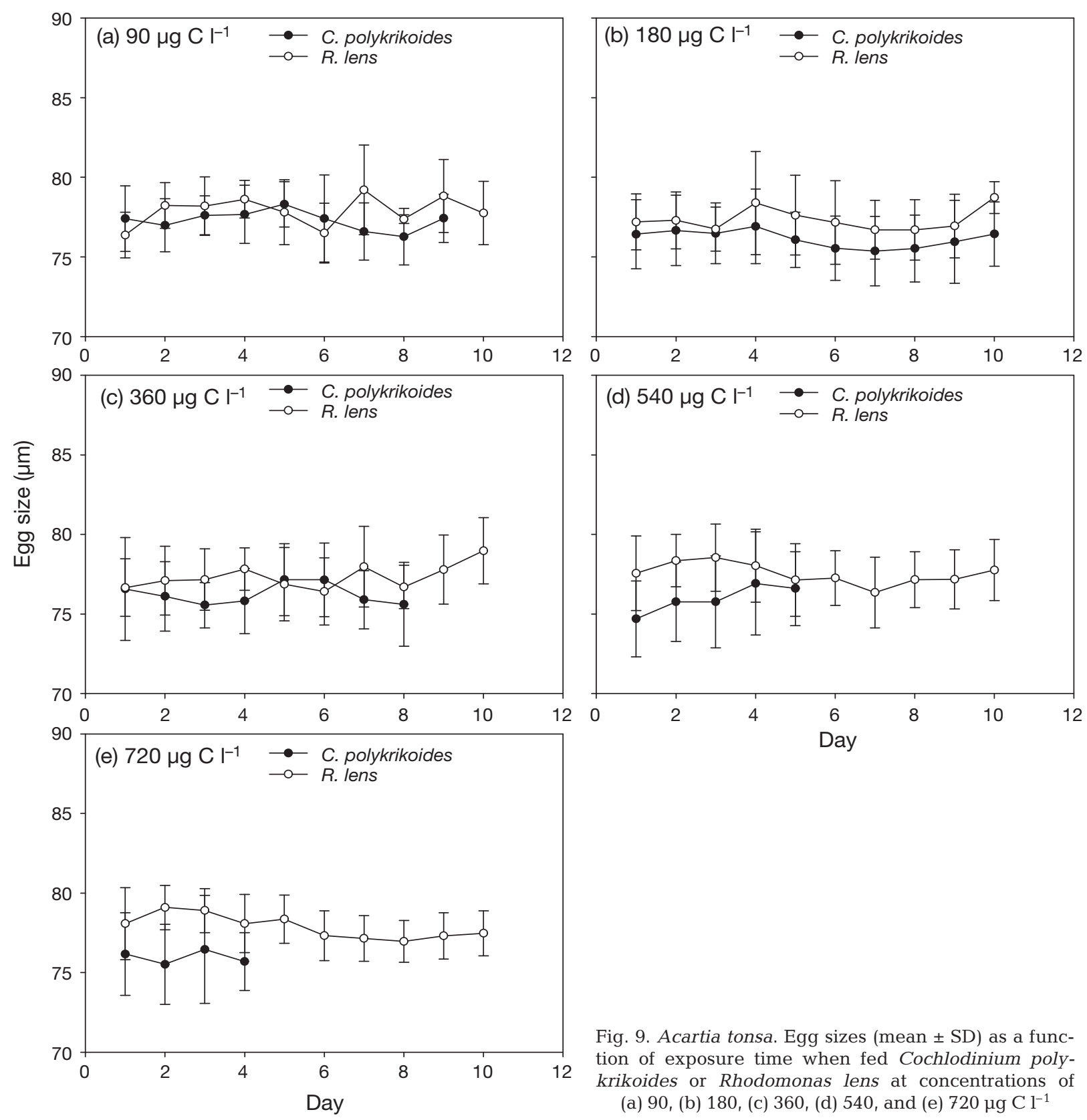

Fig. 9. Acartia tonsa. Egg sizes (mean $\pm \mathrm{SD}$ ) as a function of exposure time when fed Cochlodinium polykrikoides or Rhodomonas lens at concentrations of (a) 90, (b) 180, (c) 360, (d) 540, and (e) $720 \mu \mathrm{g} \mathrm{Cl}^{-1}$

resistance may be an important feedback mechanism to minimize the potential deleterious effects of toxic algae on zooplankton. In New York, Cochlodinium polykrikoides blooms only occur in eastern Long Island waters (Gobler et al. 2008). The copepod population used in the present study was collected from Stony Brook Harbor, Long Island Sound, where no C. polykrikoides blooms have been observed. Thus, the adverse consequences may be maximized assuming there is no zooplankton gene flow between bloom and non-bloom areas. Another potential factor is the complexity of plankton. Toxic algae rarely bloom in nature in the absence of other phytoplankters. Ingestion of $C$. polykrikoides with other concurrent phytoplankters or heterotrophic prey may dilute potential adverse effects on copepods. Some zooplankton have the ability to actively select a non-toxic diet (Turner \& Tester 1997). The adverse effects of $C$. polykrikoides may be reduced by the presence of other occurring microalgae (Tang \& Gobler 2009).

Stage-specific effects of HABs on zooplankton have rarely been considered in prior studies of the interactions between harmful algae and zooplankton. The present results showed that the susceptibility of Acartia tonsa to Cochlodinium polykrikoides decreased with development. Early nauplii of $A$. tonsa were 
4 times more sensitive to $C$. polykrikoides than adult females. These results are similar to the previous studies on stage-specific variations in sensitivity of copepods to toxic chemicals. The nauplii of Tigriopus brevicornis were 2 to 4 times more sensitive to 3 insecticides and 2 metals than the adults (Forget et al. 1998). The nauplii of $A$. tonsa were 28 times more sensitive to an organic pesticide (cypermethrin) than adults after $96 \mathrm{~h}$ of exposure (Medina et al. 2002). The greater sensitivity of copepod early life stages to toxic algae may be related to their relatively larger surface per unit volume, which may promote a greater diffusive flux of phycotoxins into the copepod body. Another possible explanation is that the later stages may have a greater ability to detoxify. Copepods may transfer toxins into fecal pellets and/or eggs, or eliminate them through excretion in dissolved form (Guisande et al. 2002). More developed metabolic systems in adults (Mauchline 1998) may improve detoxification abilities of copepods. Regardless, the studies on stage-specific effects of HABs on zooplankton may be necessary to understand their true impact on planktonic ecosystems. The investigation of all life stages also provides a more appropriate tool for predicting potential toxicity of harmful algae to copepod populations. Interestingly, live C. polykrikoides cells did not inhibit $A$. tonsa egg hatching. Tang \& Dam (2001) reported a similar result, that marine diatom exudates did not have negative effects on A. tonsa egg hatching.

Mortality of Acartia tonsa exposed to the frozen and thawed Cochlodinium polykrikoides culture was significantly lower than that in the live culture. The freezing and thawing treatment destroyed C. polykrikoides cells (authors' pers. obs.). This result indicated that harmful effects were mainly dependent on the viability of C. polykrikoides cells. Similar results were observed on the lethal effects on fish by C. polykrikoides natural bloom waters (Gobler et al. 2008, Mulholland et al. 2009) and pure cultures (Tang \& Gobler 2009). Copepod mortality exposed to the frozen and thawed $C$. polykrikoides culture was still significantly higher than that in FSW, which suggested that some harmful compound(s) remained after the freezing and thawing treatment. The extracellular secretion and continuous accumulation of polysaccharides in C. polykrikoides medium were considered to be one of the causes of fish kills (Kim et al. 2002). An extensive exocellular organic fibrillar matrix and a closely enclosing organic envelope surround the C. polykrikoides cells of the strain used in the present study (Gobler et al. 2008). The freezing and thawing treatment may not completely eliminate the harmful effect of such polysaccharides. Direct contact with those polysaccharides or other harmful compounds located on the C. polykrikoides cell surface may be responsible for the death of some copepods in this treatment. Another possibility is that some harmful compounds in C. polykrikoides may be released when cells are broken. The results from our second bioassay support these explanations. The mortality of copepods in the cages with $5 \mu \mathrm{m}$ nylon mesh and immersed in C. polykrikoides live culture was significantly lower than that in cages with $100 \mu$ m nylon mesh. The separation from harmful compounds in $C$. polykrikoides cells or on cell surfaces by the $5 \mu \mathrm{m}$ nylon mesh may account for the improved survival of copepods. Yamasaki et al. (2007) observed that cell contact with $C$. polykrikoides inhibited the growth of another dinoflagellate Akaskiwo sanguinea and caused morphologically abnormal cells. This result indicated the presence of some harmful compounds located on the C. polykrikoides cell surface, but we still do not have evidence to exclude the possibility of the presence of harmful compounds in the cells. Interestingly, the freezing of $C$. polykrikoides culture was not toxic to juvenile fish (Cypinodon variegates) (Gobler et al. 2008, Tang \& Gobler 2009). This dissimilarity is probably due to the differences in the physiology of these organisms, such as different binding sites and tolerance to harmful compounds. This harmful fraction may impact on lower trophic copepods, but not vertebrate fish.

Another harmful principle may be the dissolved, highly reactive, labile compounds released by live Cochlodinium polykrikoides cells. The complete lack of harmful effects of the $0.2 \mu \mathrm{m}$ culture filtrate suggest that C. polykrikoides cells did not release watersoluble harmful compounds or that released compounds were very unstable. The second bioassay experiment supported the latter explanation. The mortality of copepods in the cages with $5 \mu \mathrm{m}$ nylon mesh and immersed in C. polykrikoides live culture was higher than that in FSW. This result suggests that some water-soluble harmful compounds released by C. polykrikoides cells may pass through the $5 \mu \mathrm{m}$ nylon mesh and affect copepods. Kim et al. (1999) reported that ROS generated from C. polykrikoides was responsible for oxidative damage leading to fish kills. Tang \& Gobler (2009) also reported that the ichthyotoxicity of C. polykrikoides could be caused by non-hydrogen peroxide, highly reactive, labile compounds such as ROS-like chemicals. Thus, we propose that multiple harmful compounds produced by C. polykrikoides are responsible for their deleterious effects on copepods.

Cochlodinium polykrikoides significantly reduced ingestion rates of Acartia tonsa when compared to non-toxic Rhodomonas lens. Two possible mechanisms, behavioral rejection and physiological incapacitation, have been postulated to explain such reduced feeding due to harmful algae (Ives 1987). We did not directly test which mechanism was responsible for the 
reduced feeding by C. polykrikoides. Higher mortality of A. tonsa when exposed to C. polykrikoides than in FSW suggested that poisoning rather than starvation was the main mechanism for copepod death. Therefore, physiological incapacitation may at least partially explain the reduced feeding of $A$. tonsa by $C$. polykrikoides. Our present experiments, however, did not directly rule out the possibility of feeding deterrents. Copepod feeding is shaped by prey size, motility, and quality (Berggreen et al. 1988, Hansen et al. 1994, Mauchline 1998). The equivalent spherical diameters (ESD) for C. polykrikoides and $R$. lens were 28.2 and $7.97 \mu \mathrm{m}$, respectively. The optimal particle size for feeding by $A$. tonsa females is $14.8 \mu \mathrm{m}$ (Berggreen et al. 1988). Clearance rates of $A$. tonsa females were nearly equal when fed the flagellate $R$. baltica (ESD: $6.91 \mu \mathrm{m})$ and the dinoflagellate Scripsiella faröense

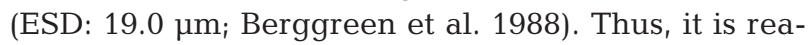
sonable to assume that the effect of size difference in the present study was limited because the 2 algae used were very similar to $R$. baltica and $S$. faröense in size. Egg sizes of $A$. tonsa when fed $C$. polykrikoides were smaller than when fed $R$. lens. To our knowledge, this is the first report that toxic algae reduced copepod egg size. Cooney \& Gehrs (1980) reported that there was a direct positive relationship between egg size and naupliar size in the calanoid copepod Diaptomus clavipes. Thus, copepod population fitness may be reduced by toxic algae, since larger nauplii usually have lower mortality rates or mature more rapidly than smaller nauplii (Mauchline 1998). We do not know the mechanism by which a C. polykrikoides diet yielded smaller eggs in $A$. tonsa. The ingestion rates of $A$. tonsa on C. polykrikoides were 25 to $60 \%$ lower than values on $R$. lens. The lack of adequate nutrition and/or physiological incapacitation would lead to impaired gametogenesis and spawning failure in copepods.

The present results clearly show that the red tide dinoflagellate Cochlodinium polykrikoides at our experimental concentrations caused deleterious consequences for the copepod Acartia tonsa. Is C. polykrikoides really a toxic alga? Harmful effects of algae on zooplankton can be explained by the absence of essential nutrients or the presence of toxins (Turner \& Tester 1997, Colin \& Dam 2002, Prince et al. 2006). One of major challenges in algae-grazer interactions is to separate potential toxic effects from nutritional inadequacy or deficiency. C. polykrikoides at high concen-

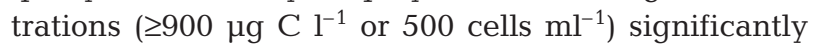
reduced survivorship of female $A$. tonsa compared to those starved in FSW. The lethal effects suggest that C. polykrikoides was a toxic prey for A. tonsa at high concentrations. Recently, the mixed-diet approach has been developed to discern whether the suspect prey is beneficial, nutritionally inadequate, or toxic to grazers
(Colin \& Dam 2002). We have also conducted mixeddiet experiments at 4 concentrations $(100,200,600$, and $1000 \mu \mathrm{g} \mathrm{C}^{-1}$ ) and 3 durations (1, 3, and $5 \mathrm{~d}$ ). The results showed that harmful effects on $A$. tonsa at $1000 \mu \mathrm{g} \mathrm{C}^{-1}$ were caused by C. polykrikoides toxicity (authors' unpubl. data). However, the nutritional value of C. polykrikoides was greater than or equal to the standard diet of Rhodomonas lens at 100 and $200 \mu \mathrm{g} \mathrm{C}$ $\mathrm{I}^{-1}$. These results showed that the nutritional value of C. polykrikoides to A. tonsa ranged from beneficial to toxic with increasing cell density. The density-dependent nutritional value of this alga suggests that $C$. polykrikoides can be nutritious or toxic for $A$. tonsa depending on ambient concentrations.

Acknowledgements. We thank 4 anonymous reviewers for their constructive comments. The research was supported by a grant from the New York Ocean and Great Lakes Ecosystem Conservation Council. This is contribution number 1383 of the School of Marine and Atmospheric Sciences.

\section{LITERATURE CITED}

Anton A, Teoh PL, Mohd-Shaleh SR, Mohammad-Noor N (2008) First occurrence of Cochlodinium blooms in Sabah, Malaysia. Harmful Algae 7:331-336

Båmstedt U, Gifford DJ, Irigoien X, Atkinson A, Roman M (2000) Feeding. In: Harris RP, Wiebe PH, Lenz J, Skjoldal HR, Huntley M (eds) ICES zooplankton methodology manual. Academic Press, New York, p 297-399

Barreiro A, Guisande C, Maneiro I, Vergara AR, Riveiro I, Iglesias P (2007) Zooplankton interactions with toxic phytoplankton: some implications for food web studies and algal defence strategies of feeding selectivity behavior, toxin dilution and phytoplankton population diversity. Acta Oecol 32:279-290

Berggreen U, Hansen B, Kiørboe T (1988) Food size spectra, ingestion and growth of the copepod Acartia tonsa during development: implications for determination of copepod production. Mar Biol 99:341-352

Cohen JH, Tester PA, Forward RB (2007) Sublethal effects of the toxic dinoflagellate Karenia brevis on marine copepod behavior. J Plankton Res 29:301-315

Colin SP, Dam HG (2002) Testing for toxic effects of prey on zooplankton using sole versus mixed diets. Limnol Oceanogr 47:1430-1437

Colin SP, Dam HG (2004) Testing for resistance of pelagic marine copepods to a toxic dinoflagellate. Evol Ecol 18: 355-377

Cooney JD, Gehrs CW (1980) The relationship between egg size and naupliar size in the calanoid copepod Diaptomus clavipes Schacht. Limnol Oceanogr 25:549-552

Curtiss CC, Langlois GW, Busse LB, Mazzillo F, Silver MW (2008) The emergence of Cochlodinium along the California coast (USA). Harmful Algae 7:337-346

> da Costa RM, Franco J, Cacho E, Fernández F (2005) Toxin content and toxic effects of the dinoflagellate Gyrodinium corsicum (Paulmier) on the ingestion and survival rates of the copepods Acartia grani and Euterpina acutifrons. J Exp Mar Biol Ecol 322:177-183

> Flynn KJ, Irigoien X (2009) Aldehyde-induced insidious effects cannot be considered as a diatom defence mecha- 
nism against copepods. Mar Ecol Prog Ser 377:79-89

Forget J, Pavillon JF, Menasria MR, Bocquené G (1998) Mortality and $\mathrm{LC}_{50}$ values for several stages of the marine copepod Tigriopus brevicornis (Müller) exposed to the metals arsenic and cadmium and the pesticides atrazine, carbofuran, dichlorvos and malathion. Ecotoxicol Environ Saf 40:239-244

Gobler CJ, Berry DL, Anderson OR, Burson A and others (2008) Characterization, dynamics, and ecological impacts of harmful Cochlodinium polykrikoides blooms on eastern Long Island, NY, USA. Harmful Algae 7:293-307

Granéli E, Flynn K (2006) Chemical and physical factors influencing toxin content. In: Granéli E, Turner JT (eds) Ecology of harmful algae. Ecological studies, Vol 189. Springer-Verlag, Berlin, p 229-241

> Guisande C, Frangópulos M, Carotenuto Y, Maneiro I, Riveiro I, Vergara AR (2002) Fate of paralytic shellfish poisoning toxins ingested by the copepod Acartia clausi. Mar Ecol Prog Ser 240:105-115

> Hairston NG, Lampert W, Cáceres CE, Holtmeier CL and others (1999) Rapid evolution revealed by dormant eggs. Nature 401:446

Hansen B, Bjørnsen PK, Hansen PJ (1994) The size ratio between planktonic predators and their prey. Limnol Oceanogr 39:395-403

Imai I, Kimura S (2008) Resistance of the fish-killing dinoflagellate Cochlodinium polykrikoides against algicidal bacteria isolated from the coastal sea of Japan. Harmful Algae $7: 360-367$

> Ives JD (1987) Possible mechanisms underlying copepod grazing responses to levels of toxicity in red tide dinoflagellates. J Exp Mar Biol Ecol 112:131-145

Jeong HJ, Yoo YD, Kim JS, Kim TH, Kim JH, Kang NS, Yih W (2004) Mixotrophy in the phototrophic harmful alga Cochlodinium polykrikoides (Dinophycean): prey species, the effects of prey concentration, and grazing impact. J Eukaryot Microbiol 51:563-569

Jeong HJ, Kim JS, Yoo YD, Kim ST and others (2008) Control of the harmful alga Cochlodinium polykrikoides by the naked ciliate Strombidinopsis jeokjo in mesocosm enclosures. Harmful Algae 7:368-377

Jester R, Rhodes L, Beuzenberg V (2009) Uptake of paralytic shellfish poisoning and spirolide toxins by paddle crabs (Ovalipes catharus) via a bivalve vector. Harmful Algae 8:369-376

Kim CS, Lee SG, Lee CK, Kim HG, Jung J (1999) Reactive oxygen species as causative agents in the ichthyotoxicity of the red tide dinoflagellate Cochlodinium polykrikoides. J Plankton Res 21:2105-2115

Kim CS, Lee SG, Kim HG (2000) Biochemical responses of fish exposed to a harmful dinoflagellate Cochlodinium polykrikoides. J Exp Mar Biol Ecol 254:131-141

Kim D, Oda T, Muramatsu T, Kim D, Matsuyama Y, Honjo T (2002) Possible factors responsible for the toxicity of Cochlodinium polykrikoides, a red tide phytoplankton. Comp Biochem Physiol C 132:415-423

> Landsberg JH (2002) The effects of harmful algal blooms on aquatic organisms. Rev Fish Sci 10:113-390

Lee DK (2008) Cochlodinium polykrikoides blooms and ecophysical conditions in the South Sea of Korea. Harmful Algae 7:318-323

Matsuyama Y, Usuki H, Uchida T, Kotani Y (2001) Effects of harmful algae on the early planktonic larvae of the oyster Crassostrea gigas. In: Hallegraeff GM, Blackburn SI, Bolch CJ, Lewis RJ (eds) Proc 9th Int Conf Harmful Algal Blooms, Feb 7-11, Hobart, Tasmania. Intergovernmental Oceano- graphic Commission (IOC), UNESCO, Paris, p 411-414

> Mauchline J (1998) The biology of calanoid copepods. Adv Mar Biol 33:1-710

> Medina M, Barata C, Telfer T, Baird DJ (2002) Age- and sexrelated variation in sensitivity to the pyrethroid cypermethrin in the marine copepod Acartia tonsa Dana. Arch Environ Contam Toxicol 42:17-22

Mulholland MR, Morse RE, Boneillo GE, Bernhardt PW and others (2009) Understanding the causes and impacts of the dinoflagellate, Cochlodinium polykrikoides, blooms in the Chesapeake Bay. Estuaries Coasts 32:734-747

Onoue Y, Nozawa K (1989) Separation of toxins from harmful red tides occurring along the coast of Kagoshima Prefecture. In: Okaichi T, Anderson DM, Nemoto T (eds) Red tide, biology, environmental science and toxicology. Elsevier, New York, p 371-374

Onoue Y, Nozawa K, Kumanda K, Takeda K, Aramaki T (1985) Toxicity of Cochlodinium type '78 Yatsushiro occurring in Yatsushiro Sea. Bull Jpn Soc Sci Fish 51:147-151

Park JG, Jeong MK, Lee JA, Cho KJ, Kwon OS (2001) Diurnal vertical migration of a harmful dinoflagellate, Cochlodinium polykrikoides (Dinophyceae), during a red tide in coastal waters of Namhae Island, Korea. Phycologia 40: 292-297

> Park TG, Park GH, Park YT, Kang YS and others (2009) Identification of the dinoflagellate community during Cochlodinium polykrikoides (Dinophyceae) blooms using amplified rDNA melting curve analysis and real-time PCR probes. Harmful Algae 8:430-440

Prince EK, Lettieri L, McCurdy KJ, Kubanek J (2006) Fitness consequences for copepods feeding on a red tide dinoflagellate: deciphering the effects of nutritional value, toxicity, and feeding behavior. Oecologia 147:479-488

Pyke DA, Thompson JN (1986) Statistical analysis of survival and removal rate experiments. Ecology 67:240-245

Shin K, Jang MC, Jang PK, Ju SJ, Lee TK, Chang M (2003) Influence of food quality on egg production and viability of the marine planktonic copepod Acartia omorii. Prog Oceanogr 57:265-277

Sokal RR, Rohlf FJ (1995) Biometry: the principles and practice of statistics in biological research, 3rd edn. WH Freeman, New York

Stoecker DK, Sieracki ME, Verity PG, Michaels AE, Haugen E, Burkill PH, Edwards ES (1994) Nanoplankton and protozoan microzooplankton during the JGOFS North Atlantic Bloom Experiment: 1989 and 1990. J Mar Biol Assoc UK 74:427-443

> Tang KW, Dam HG (2001) Phytoplankton inhibition of copepod egg hatching: test of an exudate hypothesis. Mar Ecol Prog Ser 209:197-202

Tang YZ, Gobler CJ (2009) Characterization of the toxicity of Cochlodinium polykrikoides isolates from Northeast US estuaries to finfish and shellfish. Harmful Algae 8:454-462

Turner JT (2006) Harmful algae interactions with marine planktonic grazers. In: Granéli E, Turner JT (eds) Ecology of harmful algae. Ecological studies, Vol 189. SpringerVerlag, Berlin, p 259-270

Turner JT, Tester PA (1997) Toxic marine phytoplankton, zooplankton grazers, and pelagic food webs. Limnol Oceanogr 42:1203-1214

> Yamasaki Y, Nagasoe S, Matsubara T, Shikata T, Shimasaki Y, Oshima Y, Honjo T (2007) Growth inhibition and formation of morphologically abnormal cells of Akashiwo sanguinea (Hirasaka) G. Hansen et Moestrup by cell contact with Cochlodinium polykrikoides Margalef. Mar Biol 152: 157-163

Submitted: February 22, 2009; Accepted: June 11, 2009

Proofs received from author(s): September 6, 2009 